\title{
Bibliometric Analysis of Research Trends on Acupuncture for Neck Pain Treatment Over the Past 20 Years [Letter]
}

\author{
Fan Zhang' \\ Huachun Zhang (iD ${ }^{2}$ \\ 'Department of Nephrology, Longhua \\ Hospital Shanghai University of Traditional \\ Chinese Medicine, Shanghai, People's \\ Republic of China; ${ }^{2}$ Department of \\ Nursing, Longhua Hospital Shanghai \\ University of Traditional Chinese Medicine, \\ Shanghai, People's Republic of China
}

\section{Dear editor}

We read with great interest the recent article "Bibliometric Analysis of Research Trends on Acupuncture for Neck Pain Treatment Over the Past 20 Years" published by Park et $\mathrm{al}^{1}$ in the Journal of Pain Research. However, some of the results mentioned in the original paper may be inaccurate due to the improper methodology.

Firstly, the retrieval strategy may need to be adjusted, with Park et al using acupuncture OR electroacupuncture AND cervical pain OR neck pain, while neck ache, cervicalgia, cervicodynia, cervical pain, and pharmacopuncture are also similar free words describing acupuncture and neck pain. In addition, the phrase should use double quotation marks for exact searches, while the authors did not restrict and may retrieve some publications that are not related to the topic.

Secondly, the authors should select the appropriate database for the bibliometric analysis; as described by the authors, the original article was searched in Science Citation Index Expanded (SCI-EXPANDED), Social Sciences Citation Index (SSCI), Arts \& Humanities Citation Index (A\&HCI), Conference Proceedings Citation Index- Science (CPCI-S), Conference Proceedings Citation Index- Social Science \& Humanities (CPCI-SSH), Emerging Sources Citation Index (ESCI), Current Chemical Reactions (CCREXPANDED), and Index Chemicus (IC). However, SSCI, A\&HCI, CPCI-S, CPCI-SSH, ESCI, CCR-EXPANDED, and IC are not appropriate for bibliometrics in this field.

We searched through SCI-EXPANDED using TS $=($ Neck Pain) OR $\mathrm{TS}=($ Neck Ache $)$ OR TS $=($ Cervical Pain $)$ OR $\mathrm{TS}=($ Cervicalgia $) \quad$ OR $\mathrm{TS}=$ (Cervicodynia) AND TS=(Acupuncture) OR TS $=$ (Pharmacopuncture) OR $\mathrm{TS}=($ electroacupuncture) without restriction of language or publication type. The initial retrieval yielded 347 publications, about half of the original author's results.

Therefore, it may be more helpful for readers to understand the research trend in the field of acupuncture and neck pain if the authors could further improve the bibliometric approach. 


\section{Funding}

This work was supported by Longhua Hospital Shanghai University of Traditional Chinese Medicine (Grant number: Y21026).

\section{Disclosure}

The authors report no conflicts of interest in this communication.

\section{Reference}

1. Park J, Kim H, Kim KW, et al. Bibliometric analysis of research trends on acupuncture for neck pain treatment over the past 20 years. $J$ Pain Res. 2021;14:3207-3221. doi:10.2147/JPR.S331514

Dove Medical Press encourages responsible, free and frank academic debate. The content of the Journal of Pain Research 'letters to the editor' section does not necessarily represent the views of Dove Medical Press, its officers, agents, employees, related entities or the Journal of Pain Research editors. While all reasonable steps have been taken to confirm the content of each letter, Dove Medical Press accepts no liability in respect of the content of any letter, nor is it responsible for the content and accuracy of any letter to the editor

Journal of Pain Research

Dovepress

\section{Publish your work in this journal}

The Journal of Pain Research is an international, peer reviewed, open access, online journal that welcomes laboratory and clinical findings in the fields of pain research and the prevention and management of pain. Original research, reviews, symposium reports, hypothesis formation and commentaries are all considered for publication. The manuscript management system is completely online and includes a very quick and fair peer-review system, which is all easy to use. Visit http:// www.dovepress.com/testimonials.php to read real quotes from published authors. 